\title{
STRATEGIC PLANNING OF CITY DEVELOPMENT (ON THE EXAMPLE OF KAZAN)
}

\author{
Leyla R. Kadyrova ${ }^{1}$ \\ Leysan Kh. Kashapova ${ }^{2}$
}

Abstract: The article describes the stages of development and analysis of the strategy of socio-economic development of Kazan until 2030 with the aim of structuring its content, the analysis of prospects of development of the capital of the Republic of Tatarstan, development objectives the city of Kazan, on the basis of their own capacities and competitive advantages, taking into account public priorities (representatives of the local community and businesses expressed in various discussion and project sites) for a focused «vision» of the future city Kazan, determining organizational and financial measures and tools that mobilize these resources and activity of society and the business community to achieve the goals. Also considered and structured priorities among the regulatory measures of the economic, investment and social policy, improvement of environmental situation and transformation of public spaces and architectural framework of the city. Positioned events, projects and programs, which are crucial for the effective implementation of the development strategy of Kazan and is aimed at minimizing economic risks, as reflected in the basic principle of formation of the strategy: orientation to improving the quality of life of citizens by 2030 . Proven analytical way of peritem sync with the goals and objectives of the Strategy for socio-economic development of the Republic of Tatarstan till 2030, as well as harmonization with strategic planning documents: the Federal law of June 28, 2014 No. 172-FZ «On strategic planning in the Russian Federation» and the Law «On strategic planning in the Republic of

1 Postgraduate student of Kazan Federal University, Kazan, Russia. E-mail: leilia.kadyrova@gmail.com

2 Postgraduate student of Kazan Federal University, Kazan, Russia. E-mail: leilia.kadyrova@gmail.com 
Tatarstan» (March 16, 2015 No. 12ZRT).

Keywords: Republic of Tatarstan, municipal strategy, strategic goal, the implementation of municipal strategy, the effectiveness of the strategy.

\section{INTRODUCTION}

The relevance of the topic is due to the fact that the domestic practice of developing municipal strategies has a short history, therefore the problem of municipalities strategic development is urgent [2].

In Russia formation of various regional and municipal development strategies began after the crisis of 200809. [1]. Regions feel an increased risk of dependence on the federal center. On one hand, the center does not have significant resources to support the regions, on the other, there is no long-term strategy clearly formulated and announced to the regional elites and population [5]. This created incentives for the stronger regions, with additional resources and a reliable management team to intensify the search for its own variant of economic policies with potential to accelerate the pace of growth. Such
213

regional strategies are oriented towards the maximum possible use of available financial and administrative resources of the federal center, but, in essence, are sufficiently independent of the national concepts and programs being developed in Moscow [2].

The Republic of Tatarstan has accumulated a successful experience of territorial planning. The Republic of Tatarstan acted among the regions pioneers in the development of strategies for the socio-economic development of municipal districts. When the municipal districts (city districts) development strategy is created it should be coordinated with municipal districts (city districts) that are part of the same economic zone [4].

\section{MATERIALS AND METHODS}

In the Republic of Tatarstan the legal basis for functioning of strategic planning is created and all the necessary documents are developed: the Law dated on March 16, 2015 № 12-ZRT "On Strategic Planning in the Republic of Tatarstan", the procedures for the development, adjustment, public discussion, monitoring and control of strategic planning documents were 
approved, the forecast of social and economic development of the Republic of Tatarstan was developed until 2030 (Resolution of the Cabinet of Ministers of the Republic of Tatarstan dated on May 16, 2015 № 347 "On the draft law of the Republic of Tatarstan "On the approval of the Strategy of social and economic development of the Republic of Tatarstan until 2030" and long-term forecast of economic development of the Republic of Tatarstan until 2030), the Strategy of social and economic development of the Republic of Tatarstan until 2030 was approved (the Republic of Tatarstan Law dated on June 17, 2015 № 40-ZRT "On Approving the Strategy of social and economic development of the Republic of Tatarstan until 2030") and the Action Plan for its implementation was adopted. The Republic of Tatarstan is a flagship region, which conducted an unprecedented in scope and methodological support centralized development of municipal strategies. It was synchronized with the Republican Strategy-2030, as well as republican sectorial projects and programs. Experience of the Republic of Tatarstan had been actively adopted by many regions in the implementation of the law on strategic planning, and by the Ministry of economic development of the Russian Federation for the formation of corresponding methodical base in terms of strategic planning.

To implement innovative and socially oriented scenario of the spatial development of the Republic of Tatarstan and its economic potential, it was of fundamental importance to solve the problem of centralized development of municipal strategies until 2030, synchronized with the Republican Strategy-2030.

More than twenty - year practice of developing economic programs of region municipalities as well as the results of training of the heads of municipal districts and city districts in Skolkovo served as the basis for the development of the municipal strategies of the Republic of Tatarstan. The Ministry of Economy of the Republic of Tatarstan and the State Budget Institution "Center for Economic and Social Research under the Cabinet of Ministers of the Republic of Tatarstan" prepared

"Methodological Recommendations for the Implementation of Strategic Planning for 
Social and Economic Development at the Level of Municipal Districts (Urban Districts) of the Republic of Tatarstan". The State Budget Institution "Center for Economic and Social Research under the Cabinet of Ministers of the Republic of Tatarstan" has developed a special method of conducting strategic sessions for the development of strategies for socio-economic municipal districts (city districts) using a cluster method. The essence of the method is that in one municipal district (city district) 5-6 municipalities entering into one economic zone gather to develop a "tree of problems" and solutions to them taking into account intermunicipal relations and with an eye to successful and synchronous joint development.

In February 2016, in city media and on the official website of Kazan, a report on the start of the development of the Social and Economic Development Strategy of Kazan until 2030 was published.

An online survey of Kazan residents was conducted to assess the current situation, identify problems and express the vision of "the image of the future ideal city" in 10 to 15 years. More than 800 people took part in the survey.
215

The most important stage in the development of the Kazan City Strategy was the discussion of sectoral project sites: Urban Development, Economy, Small and Medium Business, Social Sphere, Transport Infrastructure. In these spheres experts and moderators, stakeholder among the public discussed and worked out development directions of Kazan. Leading scientists of Tatarstan universities were invited to work.

Research phase is the first stage of the Strategy development. It was completed in August 2016. During this stage, about 54 different events were held. Among them are the meeting of the Strategic Council, 9 methodological seminars, 39 communication platforms, 5 interviews.

Result of the work was a database of urban problems which was collected on the basis of monitoring and surveys. The vision of the quality of life that suits the residents, a huge amount of wishes and claims from residents, systemic city problems were also the result of the work.

The results of this work are given below. 
Periódico do Núcleo de Estudos e Pesquisas sobre Gênero e Direito Centro de Ciências Jurídicas - Universidade Federal da Paraíba

V. 8 - No 05 - Ano 2019

ISSN | 2179-7137 | http://periodicos.ufpb.br/ojs2/index.php/ged/index

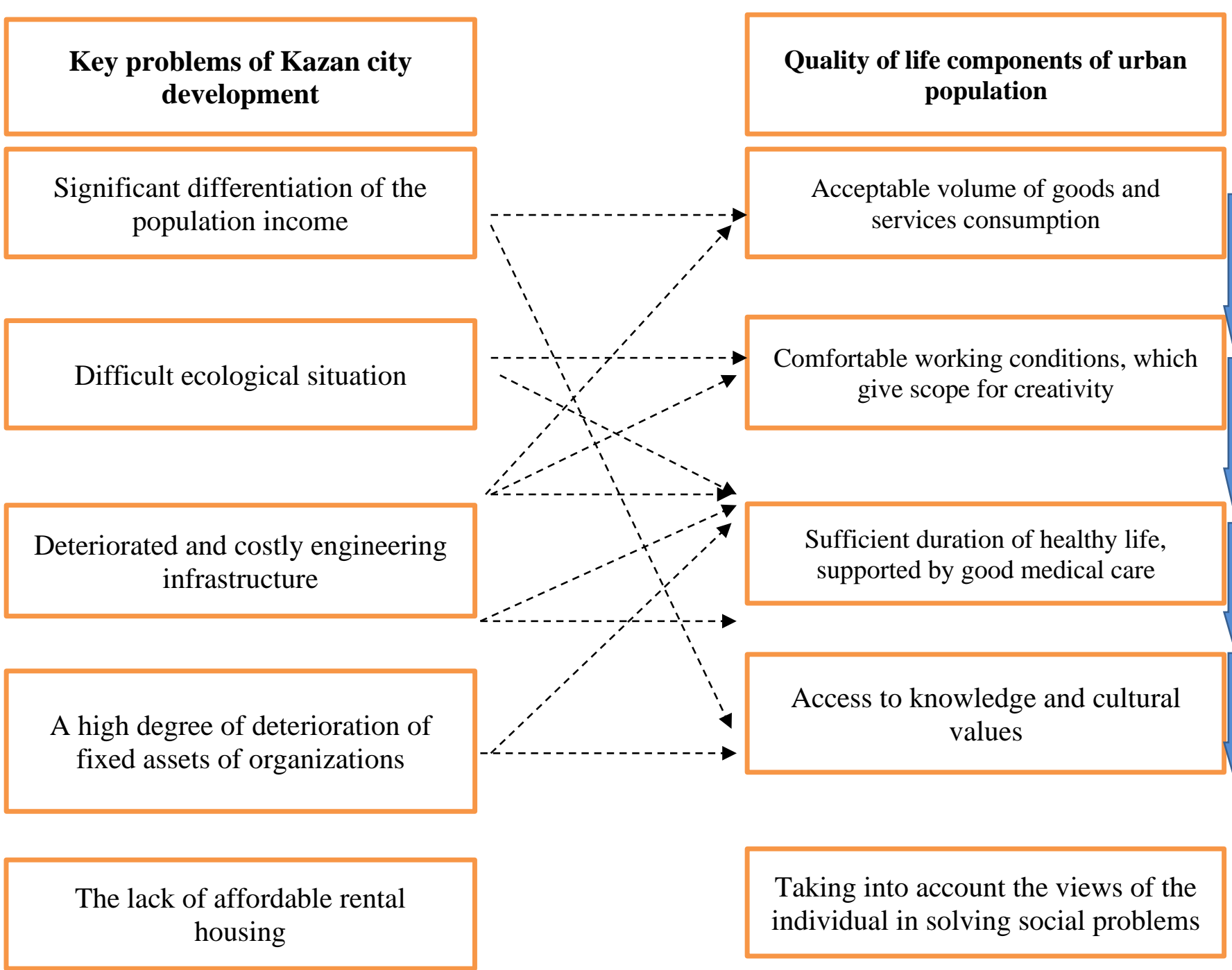

Fig. 1. Public priorities at the stage of development of the Strategy-2030 in Kazan

Based on the results of the work of the first stage, three forecast scenarios for the development of Kazan until 2030 in the field of economy, environment and human capital were formulated.

At the beginning of September 2016, the first edition of the Strategy was discussed with the participation of experts, the city's leadership, structural units of the Kazan Executive Committee, deputies of the Kazan City Duma and representatives of the public. After several stages of agreement, this Strategy 
ISSN | 2179-7137 | http://periodicos.ufpb.br/ojs2/index.php/ged/index

was approved by the decision of the Kazan City Duma in December 2016.

Analysis of the Strategy of social and economic development of Kazan until 2030 is advisable to carry out in the context of goals, objectives, as well as activities for its implementation.

The main goal is: "Kazan of 2030 is a dynamic city of sustainable economic growth and broad opportunities, the leader of the VolgaKama growth pole. Kazan is a territory of health, a comfortable city, responsible and creative citizens, an open government and a safe urban environment. A city where you want to come and where it's interesting to live every day."

The document is structured in terms of three priorities and seven areas of competition, like the Strategy of the Republic of Tatarstan-2030.

In the strategy 18 goals are formulated. They are divided into 7 areas of competition, in accordance with the landmarks that are specified in the republican Strategy. To achieve them, 42 tasks are proposed, each of which defines short-term and long-term directions of action. For the most important of them, we have established indicators to monitor their implementation.

Just like the strategy of the republic, the strategy of Kazan focuses on three areas: human capital, space and economy.

The first and most important of them is the section devoted to the attraction and formation of human capital.

A healthy lifestyle is the main priority of a person. In this regard, the main competitive advantage of the city is the presence of a healthy urban environment.

The goal of the project: Kazan2030 is a "health territory", a formation of health-saving behavior based on WHO criteria.

The proportion of the population who regularly engage in physical culture and sports will increase to $50 \%$, and the life expectancy will increase to 76 years.

The third direction of the strategy is the formation of a comfortable living space and a modern urban environment. To implement this direction, a single green pedestrian structure will be created and city priorities will be transformed - from a 
private car towards comfortable public transport. The share of green areas should be brought up to $40 \%$.

Each of the seven districts of Kazan is unique in terms of its specifics. Kazan embodies model of a polycentric city. The network of local sub-centers should seamlessly merge into the comfortable public space of the center. Moreover, efforts should be focused on relocating industrial enterprises from the historical center.

Large enterprises form the backbone of Kazan's economy, while, until 2030, a more significant contribution to the urban economy of small and medium businesses is projected.

\section{CONCLUSION}

The economy of the future will move towards small, diversified industries that actively use modern technologies and management practices. These industries produce innovative products with a high share of value added and work on the principles of selfemployment. By 2030, the city should offer entrepreneurs a simple, understandable and fully transparent rules and standards of work.
The provisions of the Strategy will be linked to monitoring of the implementation of the Action Plan and municipal targeted programs. At the same time, the regular coordinated updating of the Strategy, the Action Plan and the municipal targeted programs should be ensured.

Thus, we can conclude that the municipal strategy is synchronized with the goals and objectives of Strategy2030 of the Republic of Tatarstan.

\section{DISCUSSION}

At the same time, it is necessary to note that there are some positions, which are not indicated in the municipal strategy. Nothing is said about the plans for road construction, on improving transport junction. So, there are no corresponding organizational arrangements and no funding for these purposes.

The document also does not reflect information on major investment projects, in which work can be done both by the local population, and those who come to Kazan for permanent residence or who plan to stay after their graduation. There is even no formal analysis of the 
current situation and forecast of the development of labor resources.

In addition, nothing is said about Kazan as the center of the Kazan agglomeration. Economically weak areas surrounding the agglomeration depend on it's development because according to The Territorial Agency of the Federal State Statistics Service in the Republic of Tatarstan, Kazan has $49,18 \%$ share of industrial production the total volume of the gross territorial product of the region. In the municipal strategy there are also no indicators of assessment (and approval) of its implementation by the population.

We should say a few words about the experience of the European countries on the organization and implementation of strategic planning. The system of territorial strategic planning of each of the European countries has its own. Attention is drawn to the experience of Italy and France. According to Italian experts in the field of strategic planning, it is necessary to minimize the political influence on strategic planning, and also to reduce the number of technical requirements for it, and to involve the greatest number of interested persons from among citizens and business in this process [6].

According to French experts, citizens see the strategic plan as a tool for restoring public control over urban transformations and preparing "construction" of city institutions, provided that strategic planning is open. [7]

In order to assess the effectiveness of the implementation of the strategy, the opinion of the municipality's residents should also be taken into account [8], since the mission or the main goal of the strategic development of the territory should contribute to improving the quality of life of the population $[9,10]$.

\section{ACKNOWLEDGEMENTS}

The work is performed according to the Russian Government Program of Competitive Growth of Kazan Federal University.

\section{References}

Zubarevich N. (2010). Regions of Russia: inequality, crisis, modernization.M.: Independent Institute for social policy. 
Sirotkina N. In. Scientific and industrial clusters: theory and practice of management of the Russian regions: monograph / N. In.Sirotkin, J. A. Achenbach. - Voronezh, Publishing and printing center "Science book", 2012. 533 s.;

Smirnov V. Effective socio-economic development of the region:the paradigm and the concept / Smirnov // problems of the theory and practice of management. 2009. - No 9. - P. 55-65;

Strategic directions of socio-economic development of municipalities: the experience of the Republic of Tatarstan / N. G. Bagautdinov, I. S. Glebova, M. V. Panasyuk, V. I. Yusupova. - Kazan: publishing house of Kazan. University press, 2016. - S. 115-119;

Theoretical-methodological concepts and methodical support of strategies for socio-economic development of municipal formations in the regions of Russia/ Myasnikova T. A. // abstract of dissertation for the degree of doctor of economic Sciences.
Balducci A. Le nuove politiche della governance urbana // In Territorio. 2000. No 13. P. 7-15.

Godet M. Scerari e gestione strategica (Prospective et planification stratégique) /Edizione italiana a cura di Àntonio Mortelli; Prefoxione all'édixione inglese di H. lgorAnsoff. IPSOAS Scuola d'Impresa, 1990. 347 p.

Jourdan G. Le système de planification français au défis de la cohérence territoriale et du développement durable // Politiques publiques, ACtion politique,TErritoires (PACTE). Institut d'Études Politiques [IEP]. Grenoble CNRS: UMR5194.Université PierreMendès-France - Grenoble II. Université Joseph Fourier - Grenoble I.halshs-00374354, version 1. 8 Apr 2009.

Pinson G., Santangelo M. La planification strategique: vecteur ou subsitut a l'integration metropolitaine un detour par 1'Italie // Gouverner les métropoles: enjeux et portraits des expériences sur quatre continents / Ed. 
Periódico do Núcleo de Estudos e Pesquisas sobre Gênero e Direito Centro de Ciências Jurídicas - Universidade Federal da Paraíba V. 8 - No 05 - Ano 2019 ISSN | 2179-7137 | http://periodicos.ufpb.br/ojs2/index.php/ged/index

Collin, Jean-Pierre; Robertson, Mélanie, 2007. P. $125-150$.

Panasyuk M., Pudovik E., Malganova I.,

Butov G. Regional Multicultural

Community: Problems of Life Quality

Estimation // Mediterranean Journal of

Social Science. Vol.5. №18. P. 323-327 